\title{
Growth and Maturation of Patients with Turner's Syndrome
}

\author{
ELIZABETH PARK, ${ }^{(68)}$ JOHN D. BAILEY, AND CAROL A. COWELL \\ Department of Anthropology, University of Toronto, Departments of Paediatrics and Gynaecology, The Hospital for \\ Sick Children, Toronto, Ontario, Canada
}

Summary

The effects of sex chromosome constitution and estrogen treatment on increase in height and on skeletal and sexual maturation were studied in 116 patients with female phenotype and at least one major feature of Turner's syndrome associated with an abnormality of an $X$ chromosome. Seventy-one patients had a pure $45 X$ karyotype (XO group) and the remainder comprised 33 with $X$ chromosome mosaicism and 12 with a structurally abnormal $X$ (non-XO group).

Birth weight at all durations of gestation was similar for XO and non-XO but significantly lower than normal. Correlations of birth weight with adult height and weight were unexpectedly high, 0.96 and 0.92 respectively. Patients were significantly shorter than normal $(P<0.05)$ at all ages tested from 2-17 years, but increasingly more so after age 10. Mean adult height was $142.0 \pm 7.60$ cm $(n=28)$. Unlike most other reports there was no consistent pattern of significant differences in height between $\mathrm{XO}$ and nonXO or between Xp monosomic and Xp disomic patients.

The 13 patients $(2 \mathrm{XO}, 11$ non-XO) who experienced spontaneous menarche evidenced a slight premenarcheal growth spurt. In 11 of these 13 patients, the average growth rate increased from $3.00-4.83 \mathrm{~cm} /$ year in the year before menarche; however, this is far below the mean pubertal growth velocity of $9 \pm 1.03 \mathrm{~cm} /$ year. This observation indicates that endocrine mechanisms associated with more normal pubertal sexual development also produce a more normal pattern of growth. The estrogen-treated group grew at a lower, fairly constant rate in the 2 years before and 1 year after treatment, and total increase in height after estrogen treatment averaged only $3.6 \mathrm{~cm}$.

Rate of skeletal maturation was less than normal ( 0.53 boneage year/chronologic year) in the 2 years before treatment, and greater than normal (1.47 bone-age year/chronologic year) in the two years after treatment, suggesting that these patients may be hypersensitive to the skeletal maturing effects of estrogen.

Pretreatment breast development: absent or more delayed than pubic hair development, but the delay in both secondary sex characters was greater than the delay in skeletal maturation. At age 12, the average normal girl has moderate breast development, but at bone-age 12 , only $5.4 \%$ of our patients had moderate breast development and only $10.8 \%$ had moderate pubic hair.

Significantly but not unexpectedly more non-XO than XO patients experienced spontaneous menarche. Even the non-XO patients who require estrogen treatment may have a more normal level of ovarian function than do XO patients, who have significantly less pretreatment breast development and later epiphyseal fusion.

\section{Speculation}

In normal subjects the correlation of birth weight with adult weight is around 0.4; however, in 116 patients with Turner's syndrome, correlation with adult weight and height averaged 0.92 and 0.96 respectively, indicating that the short stature character- istic of this syndrome appears to be a consequence of intrauterine event(s). Patients treated with estrogens grew fairly constantly until an average age of $\mathbf{1 6 . 4}$ years. Those in whom menarche occurred spontaneously had experienced a slight growth spurt by then, but stopped growing at an average age of 16.0 years and were not taller as adults than the treated patients. Thus, in patients with this syndrome, sex steroids may merely speed the attainment of the predetermined growth potential.

Short stature and delayed skeletal and sexual maturation were mentioned by Turner (56) in his original description of the syndrome that bears his name. It has since been demonstrated that the major pathological defect is the congenital failure of normal gonadal development, and that affected individuals typically have an XO sex chromosome constitution (16). Short stature and delayed, or lack of sexual maturation have been documented by numerous workers $(1,7,15,20,21,23,30,32,39,47,55,60)$; however, because of the relatively low incidence of the syndrome, 1 per 5000 live births (41), and the problems associated with longterm growth studies, very few systematic studies have been based on large series (5).

The present report describes a longitudinal and cross-sectional study of height, growth, and skeletal and sexual maturation in a previously unreported series of 116 patients. Basic data were collected retrospectively, and growth and maturation of 52 patients were measured prospectively for 3 years. The effects of sex-chromosome constitution and estrogen treatment on development were examined.

\section{MATERIALS AND METHODS}

Sample. At the Hospital for Sick Children, Toronto, we reviewed the case records of all patients for whom, during 1950-1972, a diagnosis of Turner's syndrome had been queried or established. The criterion for inclusion in the study was female phenotype with lack of all or part of an X-chromosome in at least some cells. Karyotypes were routinely obtained from stimulated lymphocytes; in cases of possible mosaicism, fibroblasts were usually cultured as well. The 116 patients selected included 71 with an XO sex chromosome constitution; the non-XO individuals comprised 33 with $X$ chromosome mosaicism and 12 with a structurally abnormal X (Table 1). Nearly half of the XO patients were identified at birth $(23.2 \%)$ or between $10-15$ years $(24.6 \%)$; $62.2 \%$ of the non-XO patients were identified between $10-20$ years of age. Significantly more $\mathrm{XO}$ than non-XO cases were diagnosed before 10 years of age $(P<0.05)$. Edema of the newborn and/or congenital malformations led to the diagnosis of $24.6 \% \mathrm{XO}$ and no non-XO. Short stature, alone or with other features, led to the diagnosis of $58 \% \mathrm{XO}$ and $60.5 \%$ of non-XO. Overall, the commonest clues to diagnosis: short stature alone $(30.7 \%)$ or with delayed puberty $(16.6 \%)$, neonatal edema and congenital malformation (10.5\%), delayed puberty alone $(8.7 \%)$ and congenital malformation alone $(7.9 \%)$. XO patients had a higher incidence of 
all stigmata common to the syndrome (Table 2). The difference was significant $(P<0.05)$ for all except short stature and hypertension.

Growth data. Birth weight (with known duration of gestation) of 99 patients was compared with normal standards $(29,59)$ and was correlated with weight and height up to maturity. Of the 550 height measurements obtained (at least one for each patient, and the majority between 10-20 years), 150 were made prospectively by Elizabeth Park and 400 were from the endocrine clinic records. The stage of skeletal maturation was used to group patients by similar biologic, rather than chronologic age. In 120 cases, height measurements were related to a radiograph of the hand and wrist, and in 201 cases the bone age was estimated from its regression on chronologic age (44). The regression of bone age on chronologic age proved to be almost a perfect straight line, so it was considered reasonable to estimate bone ages between age 5 and age of treatment or menarche. If there was no real bone age within 2 years of a regression-derived bone age, the derived bone age and its associated height were used. If there was a real bone age within 2 years of a derived bone age, the latter was used only if it would produce a rate of skeletal maturation between $0.5-1.5$ bone age years per chronologic year. This method greatly increased the number of heights which could be grouped by bone age. Bone age 1-17 years (adult) was determined from published standards for

Table 1. Sex-chromosome constitution of the sample

\begin{tabular}{|c|c|c|c|c|c|}
\hline \multirow{3}{*}{$\begin{array}{c}\begin{array}{c}\text { Type of X-chromo- } \\
\text { some }\end{array} \\
\text { Aberration }\end{array}$} & \multirow{3}{*}{$\begin{array}{c}\text { Sex chromosome } \\
\text { Constitution }\end{array}$} & \multicolumn{4}{|c|}{ Patients } \\
\hline & & \multirow[b]{2}{*}{ No. } & \multirow[b]{2}{*}{$\%$} & \multicolumn{2}{|c|}{ Total } \\
\hline & & & & No. & $\%$ \\
\hline Pure X monosomy & Xo & & & 71 & 61.2 \\
\hline \multirow[t]{9}{*}{ Mosaicism } & & & & 33 & 28.5 \\
\hline & $\mathrm{XO} / \mathrm{XX}$ & 13 & 11.2 & & \\
\hline & $\mathrm{XO} / \mathrm{XXqi}$ & 9 & 7.8 & & \\
\hline & $\mathrm{XO} / \mathrm{XXr}$ & 2 & 1.7 & & \\
\hline & $\mathrm{XO} / \mathrm{XXX}$ & 1 & 0.9 & & \\
\hline & $\mathrm{XO} / \mathrm{XX} / \mathrm{XXX}$ & 2 & 1.7 & & \\
\hline & Complex mosaic ${ }^{1}$ & 2 & 1.7 & & \\
\hline & $\mathrm{XO} / \mathrm{XY}$ & 3 & 2.6 & & \\
\hline & $\begin{array}{l}\mathrm{XO} / \mathrm{XX}-\mathrm{D} \text { translo- } \\
\text { cation }\end{array}$ & 1 & 0.9 & & \\
\hline \multirow[t]{4}{*}{ Structural aberration } & & & & 12 & 10.3 \\
\hline & XXqi & 7 & 6.0 & & \\
\hline & $\mathrm{XXp}-$ & 3 & 2.6 & & \\
\hline & $\mathrm{XXq}-$ & 2 & 1.7 & & \\
\hline
\end{tabular}

${ }^{1}$ XO/XX/XXqi; Xo/XX/XXqi/XXqiXqi/XXXqi.

Table 2. Stigmata of Turner's syndrome in the sample

\begin{tabular}{lccc}
\hline \multicolumn{1}{c}{ Stigmata $^{1}$} & XO (\%) & Non-XO (\%) & Overall (\%) \\
\hline Short stature $^{2}$ & 100.0 & 95.2 & 98.0 \\
Cubitus valgus $_{\text {Short wide neck }}$ & 93.3 & 64.1 & 81.8 \\
Widely spaced nipples $^{3}$ & 91.5 & 54.5 & 77.4 \\
Shield chest & 90.0 & 52.3 & 75.4 \\
Low posterior hairline & 81.4 & 40.9 & 67.3 \\
Webbed neck & 76.9 & 36.8 & 62.1 \\
$\quad$ Congenital renal abnor- & 78.9 & 13.6 & 53.9 \\
$\quad$ malities & 33.4 & 11.1 & 24.1 \\
$\quad$ Congenital cardiac ab- & 31.0 & & \\
$\quad$ normalities & & 8.8 & 22.5 \\
Hypertension & 13.8 & 10.0 & 12.4 \\
\hline
\end{tabular}

$1 \%$ are based on observations on at least $80 \%$ of the 116 cases.

${ }^{2}>-2$ S.D. for age.

${ }^{3}$ This was based on visual impression only. This impression may result from the chest being disproportionately wide, rather than the nipples being absolutely widely spaced. females (19). Height was compared statistically by $t$ test ${ }^{70}$ with published standards for normal females (51). The height of XO and non-XO patients was compared at all ages.

To test the hypothesis that monosomy of the short arm of $X$ $(\mathrm{Xp})$ is the cause of short stature in Turner's syndrome (13), patients monosomic for $\mathrm{Xp}(\mathrm{XO}, \mathrm{XXqi}, \mathrm{XXp}-)$ were compared with those disomic for $\mathrm{Xp}$ in some or all cells ( $\mathrm{XO}$, $\mathrm{XX}, \mathrm{XXX}, \mathrm{XXq}-$ ).

Maturation data. EP rated 160 radiographs of the left hand and wrist (19) and compared the data statistically with Brush Foundation standards for normal females (47). Information on breast and pubic hair development, collected from the case records, was scored as 0 (no development), 1 (slight) 2 (moderate development) or 3 (adult). ${ }^{71}$ Individuals were grouped, by bone age and $\%$, with each calculated stage of breast and pubic hair development.

Effect of estrogen treatment or menarche on development. Thirtyeight patients received cyclical estrogen replacement, at a mean age of 17.0 years; 13 (two of $23 \mathrm{XO}$ and 11 of 28 non-XO) experienced spontaneous menarche, at a mean age of 13.4 years (Table 3), which is similar to the current North American mean age of 12.7 years (66). For analysis, age at initiation of estrogen therapy and menarche (events that are not equivalent endocrinologically) were considered equivalent. To calculate height velocity, age at either event was considered zero, and any two heights before or after 0 were used to calculate velocity, dividing height increment by time. This calculated velocity was plotted at the midpoint of the interval. Velocities were calculated up to 2 years before and after 0 , and grouped into four 1-year groups ( 2 years to 1 year before; 1 year before $0 ; 0-1$ year after; and $1-2$ years after), and means were calculated for treated and untreated subjects. Finally, average growth after starting treatment or after menarche and the age at which growth ceased were calculated.

The rate of skeletal maturation was determined using a method similar to that for height. The effect of treatment on fusion of the epiphyses was assessed by grouping radiographs into 2 years before and 2 years after treatment. Bones were grouped by row: radius and ulna, metacarpals, and proximal, middle, and distal phalanges. Fusion of each epiphysis was rated as 0 (none), 1 (in progress), or 2 (complete). The number of patients with any evidence of fusion before treatment was subjected to $\chi^{2}$ testing of $\mathrm{XO}$ versus non-XO. For analysis of secondary sexual maturation, the patients were grouped by the number of years before and after zero time, and \% with various combinations of breast and pubic hair development were calculated for each group.

\section{RESULTS}

All results are reported as mean \pm S.D. Differences were considered significant at the 0.05 level.

Table 3. Patients who experienced spontaneous menarche, by karyotype and age at menarche

\begin{tabular}{|c|c|c|}
\hline Karyotype & $\begin{array}{l}\text { Age at } \\
\text { menarche }\end{array}$ & Comments \\
\hline XO & 13.5 & \\
\hline XO & 13.0 & \\
\hline $\mathrm{XO} / \mathrm{XX}$ & 13.2 & \\
\hline $\mathrm{XO} / \mathrm{XX}$ & 12.8 & \\
\hline $\mathrm{XO} / \mathrm{XX}$ & 13.0 & \\
\hline $\mathrm{XO} / \mathrm{XX}$ & 15.0 & $\begin{array}{l}\text { Irregular periods; estrogen treatment } \\
\text { at age } 23\end{array}$ \\
\hline $\mathrm{XO} / \mathrm{XX} / \mathrm{XXX}$ & 15.5 & $\begin{array}{l}\text { Pregnant at age 19. Normal infant } \\
(46 \mathrm{XX})\end{array}$ \\
\hline $\mathrm{XO} / \mathrm{XX} / \mathrm{XXX}$ & 16.1 & \\
\hline $\mathrm{XO} / \mathrm{XXqi}$ & 12.0 & $\begin{array}{l}\text { Irregular periods; estrogen treatment } \\
\text { at age } 17.5\end{array}$ \\
\hline $\mathrm{XO} / \mathrm{XXqi}$ & $?$ & \\
\hline $\mathrm{XO} / \mathrm{XXr}$ & 12.7 & \\
\hline $\mathrm{XXp}-$ & 11.0 & \\
\hline $\mathrm{XXp}-$ & 14.0 & Secondary amenorrhea at age 25 . \\
\hline
\end{tabular}


Birth weight. Duration of gestation was $39.5 \pm 1.74$ wk overall and did not differ significantly for $\mathrm{XO}$ and non-XO patients. Birth weights of all gestations were similar for the two groups but significantly lower than normal (Table 4). Correlations of birth weight with weight and height at bone ages 9-17 years were surprisingly high, chiefly in the range of $0.75-0.95$ (Table 5). The nonconforming results for age 16 may reflect the low $n$ in comparison with adjacent ages.

Height. The patients were significantly shorter than normal at all ages tested, from 2-17 years (Fig. 1). Mean height was below but parallel to normal from 5-12 years, then fell off more markedly. At almost every age, it was at or 2 S.D. below normal. Until the expected age of puberty, growth velocity was within the normal range. Final height, at bone age 17 years, was $142.0 \pm$ $7.60 \mathrm{~cm}(n=28)$, with a range of $131.2-167.0 \mathrm{~cm}$. On average, the height of adult patients approximated that of a normal girl aged 10-11 years.

There was no consistent significant difference in the height of $\mathrm{XO}$ and non-XO patients (Fig. 2). Although XO were taller at ages 14 and 16 , non-XO were slightly, but not significantly taller as adults. S.D. of height was less for XO than non-XO, indicating more homogeneity among the former. There was no evidence that the XX cell line had a modifying effect on short stature. For instance, at bone age 13, when $n$ was largest, mean height of $9 \mathrm{XO}$ and $8 \mathrm{XO} / \mathrm{XX}$ patients was $140.6 \mathrm{~cm}$ and $139.4 \mathrm{~cm}$, respectively. Height comparisons between $\mathrm{Xp}$ monosomic and $\mathrm{Xp}$ disomic patients revealed no consistent pattern of significant differences (Fig. 3).

Maturation. Hand and wrist bone age was significantly below normal from age 5-16, the last age tested (Fig. 4). By 3 years (the youngest for which data were available) bone age was below normal. It remained at fairly constant subnormal levels until age 10 , then fell off until age 13 and much more sharply thereafter. The greatly retarded bone age at later chronologic ages relates to the late age of estrogen treatment plus a bias toward radiographing girls in whom bone-age retardation was suspected. It was therefore

Table 4. Birth weight of patients with Turner's syndrome and normal subjects

\begin{tabular}{llrccc}
\hline \multirow{2}{*}{$\begin{array}{c}\text { Duration of gesta- } \\
\text { tion }\end{array}$} & & & \multicolumn{2}{c}{ Birth weight $(\mathrm{kg})$} \\
\cline { 5 - 6 } & Type of individual & $n$ & Mean & S.D. \\
\hline All durations & Patients & 99 & 2.86 & 0.554 \\
All durations & $\begin{array}{c}\text { Normal female } \\
\text { subjects (29) }\end{array}$ & 1000 & 3.41 & 0.455 \\
$40 \mathrm{wk}$ & XO patients & 39 & 2.94 & 0.536 \\
$40 \mathrm{wk}$ & Non-XO patients & 25 & 2.90 & 0.500 \\
$40 \mathrm{wk}$ & $\begin{array}{l}\text { All patients } \\
\text { Normal female }\end{array}$ & 64 & 2.92 & 0.518 \\
& subjects (58) & 47 & 3.48 & 0.460 \\
& & & & & \\
\hline
\end{tabular}

Table 5. Correlations between birth weight and subsequent weight and height

\begin{tabular}{cccccc}
\hline & $\begin{array}{c}\text { Birth weight and adult } \\
\text { weight }\end{array}$ & & \multicolumn{2}{c}{$\begin{array}{c}\text { Birth weight and adult } \\
\text { height }\end{array}$} \\
\cline { 2 - 3 } \cline { 5 - 6 } Bone age (yr) & $n$ & $r$ & & $n$ & $r$ \\
\hline 9 & 17 & $0.81^{1}$ & & 17 & $0.84^{1}$ \\
10 & 23 & $0.75^{1}$ & & 24 & $0.80^{1}$ \\
11 & 30 & $0.88^{1}$ & & 34 & $0.84^{1}$ \\
12 & 32 & $0.83^{1}$ & & 32 & $0.89^{1}$ \\
13 & 34 & $0.89^{1}$ & & 40 & $0.89^{1}$ \\
14 & 18 & $0.85^{1}$ & & 17 & $0.95^{1}$ \\
15 & 21 & $0.89^{1}$ & & 20 & $0.91^{1}$ \\
16 & 12 & 0.05 & & 11 & 0.11 \\
17 & 20 & $0.92^{1}$ & & 19 & $0.96^{1}$ \\
\hline
\end{tabular}

${ }^{1}$ Significant $(P<0.05)$.

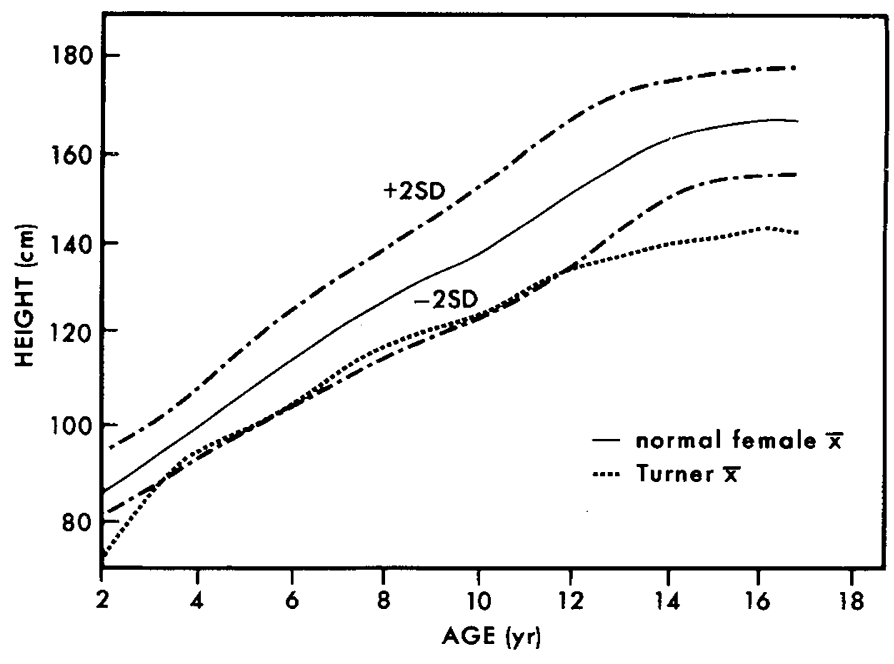

Fig. 1. Height of patients with Turner's syndrome and of normal females, at bone age $2-17$ years.

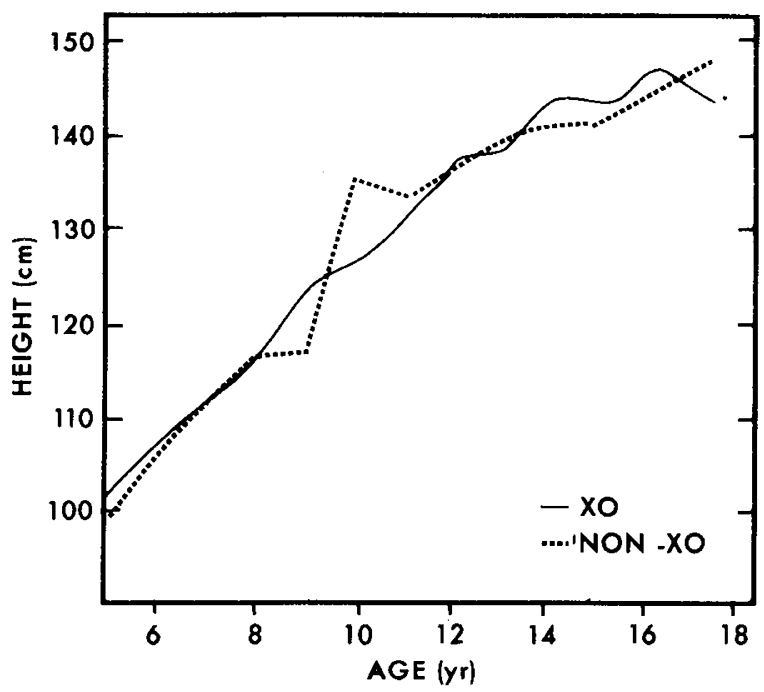

Fig. 2. Height of $\mathrm{XO}$ and non-XO patients at bone age 5-17 years.

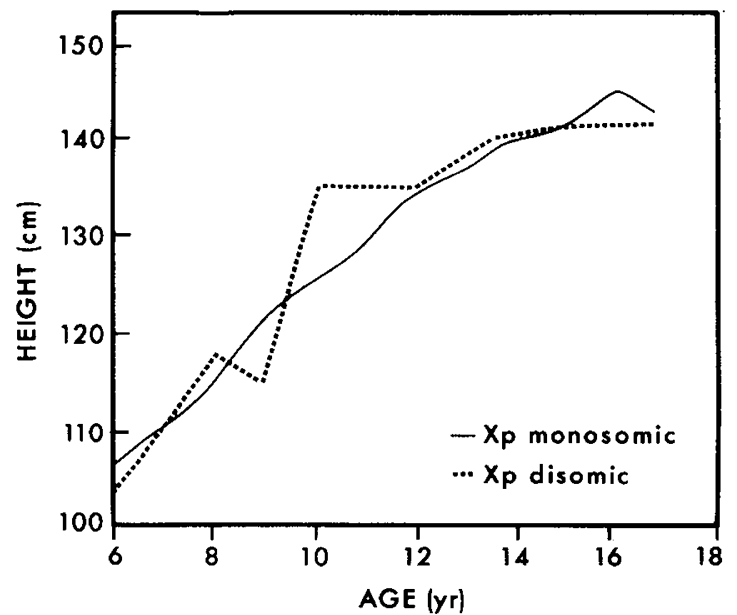

Fig. 3. Height of $\mathrm{Xp}$ monosomic and $\mathrm{Xp}$ disomic patients at bone age 6-17 years.

difficult to determine the age at which complete epiphyseal fusion of the hand and wrist was reached, and this in turn related to the age at which estrogen treatment was started. Extrapolation of skeletal maturation indicated attainment of adult bone age at chronologic age 19 years. 


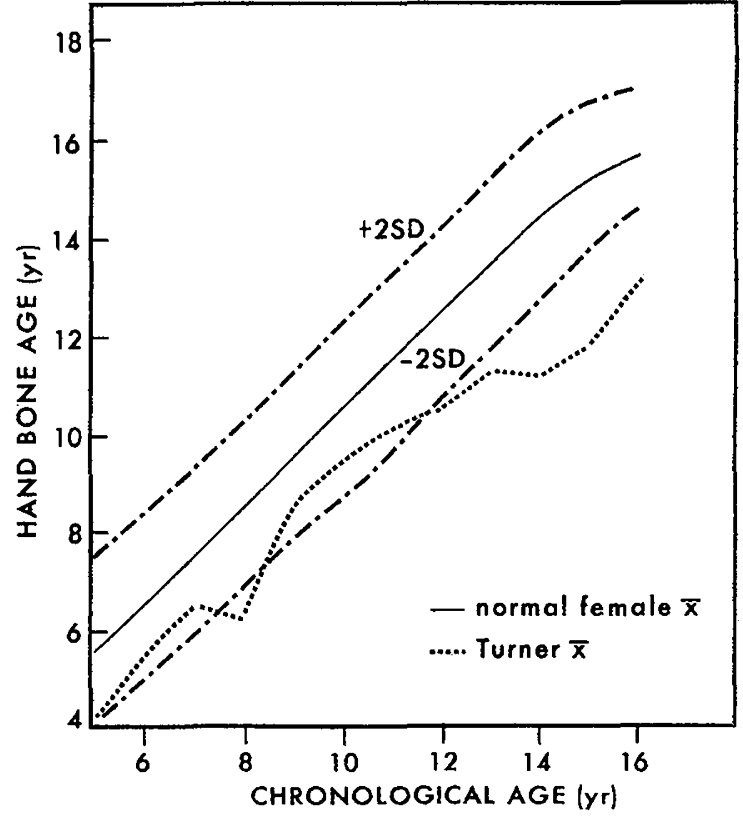

Fig. 4. Hand bone age plotted against chronological age for Turner patients and normal females.

No breast or pubic hair development was noted before bone age 9.3 In general, up to bone age 15 , pubic hair development was more:advanced than breast development, but at bone age 17 it had reached only stage 1 in five of 29 patients. Often in this condition there is no breast development without treatment and in this series very little breast development was noted before bone age 12 , and at bone age 17 it was only moderate in six of 29 patients.

Effect of estrogen treatment/menarche on development. Mean height velocities are shown in Table 7 . The group of 13 patients who experienced spontaneous menarche evidenced a slight growth spurt before menarche, growing faster than did the treated group before treatment. The treated group had a fairly constant growth rate in the 2 years before and 1 year after treatment. In the second year after either menarche or treatment, the growth rate declined to $1 \mathrm{~cm}$ /year. Growth after treatment averaged $3.6 \mathrm{~cm}$. in 2.7 years. Data on the amount of growth after spontaneous menarche were absent. The duration of growth after treatment or spontaneous menarche was the same about $2 \frac{1}{2}$ years, but the treated group ceased growth 3.4 years later. There was no significant difference in the final height of the two groups.

In general, bone age did not advance beyond 13.5 years before treatment or spontaneous menarche, and in most cases was between 12.5-13.5 years in the year before this event. Bone age velocity was less than normal ( 0.53 bone age year/chronologic year) in the 2 years before, and greater than normal (1.47 bone age year/chronologic year) in the 2 years after treatment. The sequence of epiphyseal fusion was the same as for normal girls.

In the year before treatment, fusion was in progress or complete in the metacarpals in $30.4 \%$, proximal phalanges in $13.0 \%$, middle phalanges in $17.1 \%$, distal pahlanges in $69.8 \%$, and radius and ulna in $13.0 \%$ (see 45 ); it was observed significantly more often in non-XO $(91.7 \%)$ than in XO patients $(44.4 \%)$. After treatment there was a marked increase in fusion in all bone categories. In the first year after treatment, fusion was in progress or complete in the metacarpals in $50.0 \%$, proximal phalanges in $50.0 \%$, middle phalanges in $43.7 \%$, distal phalanges in $75.0 \%$, and radius and ulna in $31.1 \%$. By 2 years after treatment, fusion was virtually complete in all bone categories except radius and ulna.

In the 6 months before treatment, $82.5 \%$ of the patients had some pubic hair and $55.6 \%$ has some recorded breast development. Pubic hair developed in $92.8 \%$ of $\mathrm{XO}$ and $78.6 \%$ of non-XO patients, whereas breast development occurred in significantly
Table 6. Pubic hair development at bone age 9-17 years

\begin{tabular}{|c|c|c|c|}
\hline \multirow[b]{2}{*}{ Bone age (yr) } & \multicolumn{2}{|c|}{ Pubic hair development } & \multirow[b]{2}{*}{$\%$} \\
\hline & Stage & No. & \\
\hline \multirow[t]{5}{*}{9} & 0 & 15 & 93.8 \\
\hline & 1 & 1 & 6.2 \\
\hline & 2 & 0 & \\
\hline & 3 & 0 & \\
\hline & & 16 & \\
\hline \multirow[t]{5}{*}{11} & 0 & 12 & 30.0 \\
\hline & 1 & 28 & 70.0 \\
\hline & 2 & 0 & \\
\hline & 3 & 0 & \\
\hline & & 40 & \\
\hline \multirow[t]{5}{*}{13} & 0 & 7 & 15.2 \\
\hline & 1 & 21 & 45.7 \\
\hline & 2 & 13 & 28.3 \\
\hline & 3 & 5 & 10.9 \\
\hline & & 46 & \\
\hline \multirow[t]{5}{*}{15} & 0 & 0 & \\
\hline & 1 & 0 & \\
\hline & 2 & 2 & 8.7 \\
\hline & 3 & $\underline{21}$ & 91.3 \\
\hline & & 23 & \\
\hline \multirow[t]{5}{*}{17} & 0 & 0 & \\
\hline & 1 & 5 & 17.2 \\
\hline & 2 & 2 & 6.9 \\
\hline & 3 & $\underline{22}$ & 75.9 \\
\hline & & 29 & \\
\hline
\end{tabular}

Table 7. Height velocity in relation to treatment or menarche

\begin{tabular}{lcccc}
\hline & \multicolumn{4}{c}{ Height velocity } \\
\cline { 2 - 4 } Years before or & \multicolumn{2}{c}{ Treatment } & & \multicolumn{2}{c}{ Menarche } \\
\cline { 2 - 5 } \cline { 5 - 5 } after the event & $n$ & Mean (cm/yr) & $n$ & Mean (cm/yr) \\
\hline-2 to -1 & 16 & 2.35 & 2 & 3.00 \\
-1 to 0 & 21 & 2.55 & 4 & 4.83 \\
0 to +1 & 23 & 2.88 & 4 & 2.09 \\
+1 to +2 & 16 & 1.03 & 2 & 0.93 \\
\hline
\end{tabular}

more non-XO (71.4\%) than XO (38.5\%) patients. It should be noted that this could be an overestimate because in girls with an obese chest wall it was occasionally difficult to distinguish developing glandular tissue from adipose tissue. By 1 year after treatment, $60.0 \%$ had moderate pubic hair and breast development. By 2 years this number had risen to $68.3 \%$, and at the end of the third year virtually all had moderate or adult breast development and pubic hair.

\section{DISCUSSION}

In Turner's syndrome, disruption in development begins before birth. It has been estimated that $98 \%$ of XO conceptions end in spontaneous abortion (10), and many fetuses who survive to term have genital, cardiac, renal and dermal abnormalities. The findings of significantly decreased birth weight of infants with Turner's syndrome after gestation of normal duration (38-42 wk) in this and other studies $(5,9,34)$ indicate that weight growth is adversely affected. In one study (5), the average birth length of 36 infants was significantly below normal.

There is limited information on the growth of patients with Turner's syndrome during infancy and early childhood; however, 
this and other studies $(5,20,21,31)$ have shown that, on average, the height by the age of $4-5$ years is 2 S.D. below that of normal girls and remains there until, at the expected age of puberty, it falls off sharply to an average of 4.5 S.D. below normal in adulthood. (It should be remembered that these data are based largely on retrospective studies of patients identified because they displayed features typical of the syndrome, undoubtedly are biased toward increased abnormality of growth).

Precisely why stature should be so greatly affected is not known. Short stature is a feature of several chromosomal aneuploidies (52), but it is only the sex chromosome abnormalities involving complete or partial loss of a sex chromosome that are associated with short stature. XXX is associated with normal or possibly tall stature $(3,42)$, and XXY and XYY with tall stature $(24,50)$. According to the Lyon hypothesis (38), only one $\mathrm{X}$ remains active in each somatic cell in man, any additional $X$ chromosomes being randomly inactivated several weeks after conception (40). Critical events may occur during this interval. In addition there is recent convincing evidence that a region on the distal end of Xp escapes inactivation (43). Cell death after inactivation of the single $X$ in some cells has been proposed (18) as a cause of abortion and growth deficiency in this syndrome. Barlow (2), observing that the mitotic cycle of $\mathrm{XO}$ cells in vitro is increased, suggested that persons with an XO complement or variant may reach critical development milestones with an abnormal cell population, and therefore manifest abnormal growth. In the normal population correlation of birth weight with adult weight is fairly low: 0.4 (54). In the present study, correlations of birth weight with adult weight and height were 0.96 and 0.92 respectively. This supports the theory that factors operating prenatally significantly affect growth potential in Turner's syndrome.

If absence of an $\mathrm{X}$ chromosome results in short stature, it might be expected that a mosaicism $(\mathrm{XO} / \mathrm{XX})$ with a normal $\mathrm{XX}$ cell line would be conducive to more normal stature. This was not the case; however, sample size at any one age was only $2-8$. Our review of published cases $(12,13,34,39,57,64)$ showed that adult $\mathrm{XO} / \mathrm{XX}$ subjects $(148.8 \pm 5.86 \mathrm{~cm} ; n=18)$ were significantly taller than XO subjects ( $142.4 \pm 6.21 \mathrm{~cm} ; n=59)$, as reported by others (49). Thus there is evidence that the XX cell line exerts an ameliorating effect on shortness of stature. It should be pointed out that most of the patients came to us in the paediatric age range because of concern over stature with or without delayed puberty. Those individuals with mosaic sex chromosomes or structural X abnormalities, particularly those in the taller height range with no obvious stigmata of Turner's syndrome might not come to medical attention until a much later age, particularly if there is some ovarian function. This type of case selection, especially in nonXO's, might be a factor in surveys relating to adult height, and should also be taken into consideration when discussing results of treatment with anabolic steroids. The height of our XO patients was similar to most reported series e.g., 5 where estrogen treatment was begun at an earlier age. This indicates that the earlier treatment doesn't have a detrimental effect on height.

A more specific theory has been advanced (13) that genetic loci concerned with stature are located on the short arm of the $X$ chromosome (Xp). This idea has gained widespread acceptance $(17,18,25,27)$ but is not supported by the present analysis comparing $\mathrm{Xp}$ monosomic and $\mathrm{Xp}$ disomic individuals. Further, of the three XXp- patients, two are very short ( -3 S.D.) but one is of normal stature $(167.0 \mathrm{~cm})$. In the published series cited above, totalling 105 adult subjects, four were of a height $>-2$ S.D;; two of these, who were XXp-, were 156.0 and $158.5 \mathrm{~cm}$ tall. There are also XXq- persons on record who are short $(4,22,25,36)$. It may be that height is more dependent on genes on $\mathrm{Xp}$ than on genes on Xq. The mean height of XXpi subjects has been reported as $157.1 \mathrm{~cm}$ above the height of XO patients but well below that of normal females. Alternatively, the features of Turner's syndrome, including short stature, may relate to the amount of $X$ chromosome material lost rather than loss of a specific segment of $X(65)$. Since this series was assembled, an additional patient, (B.L.), has come to our attention exhibiting short stature $(145.3 \mathrm{~cm}$ at 17 years) and streak gonads with $46 \mathrm{XX}$ karyotype; however, there is a small area of abnormal banding in the long arm of the $X$, the exact nature of which has not yet been clarified, which indicates that even minor variance in sex chromosomes can lead to severe short stature and abnormal gonadal development. The documentation and pooling of larger series together with chromosome banding may help clarify the situation. For the present, it seems premature and misleading to state that only those patients with Turner's syndrome who are monosomic for Xp are short.

The marked slowing of increase in stature of patients with Turner's syndrome at the expected age of puberty has been attributed to failure to undergo a growth spurt $(26,30,35)$. Although we could not construct a general height velocity curve, our data show that patients who required estrogen treatment did not evidence a growth spurt before or after treatment, whereas those who experienced spontaneous menarche showed the expected increase in growth rate during the year before menarche; however, this was below the usual growth velocity. This observation, although based on only 11 patients, indicates that endocrine mechanisms associated with more normal pubertal sexual development also produce a more normal pattern of pubertal growth; however, those who experienced spontaneous menarche were not significantly taller as adults than those requiring treatment. Increase in height after estrogen treatment totalled only $3-4 \mathrm{~cm}$ as reported by others $(6,11,20,23)$, which indicates that once bone age has reached about 13 years less than $5 \mathrm{~cm}$ of growth can be expected after estrogen treatment.

Although none of the subjects in this series received any growth promoting agent, several studies have investigated the effect on growth of anabolic agents such as fluoxymesterone and oxandrolone $(28,37,44,49,58)$. These agents have been shown to increase growth velocity in girls with Turner's syndrome especially during the first year of treatment. There have not been sufficient long term studies to show if there will be consistent improvement in adult height.

Bone age in these patients is below normal during early childhood, but only in few cases is this of such degree as to be clinically significant. The great delay in skeletal maturation at the expected age of puberty is commonly attributed to the lack of ovarian hormones, primarily estrogens $(1,11,32,62)$. This is supported by our finding that bone-age maturation slows to a rate less than normal ( 0.53 bone age year/chronologic year) before the start of treatment of menarche, and increases to a rate above normal (1.47 bone age year/chronologic year) afterwards. Slightly supranormal rates of skeletal maturation have been reported (5), suggesting that these patients may be hypersensitive to the skeletal-maturing effects of estrogens.

In few cases, did pretreatment bone age advance beyond 13.5 years, the stage when epiphyseal fusion starts (19). Particular examination of the hand epiphyses revealed that fusion continued, in normal sequence but much slower than normal. Occasional reports of cases, presumably diagnosed late and not treated with estrogens $(5,30,32,46)$, indicate that fusion proceeds very slowly and is complete in the hand by the middle twenties. Slow but eventual fusion of hand epiphyses may come about through the action of adrenal androgens which, in addition to promoting growth of sexual hair, bring about skeletal maturation (48). This theory is supported by the observation that before treatment or menarche no fusion was evident in patients with no pubic hair but was in progress in all but two who had moderate pubic hair. Pretreatment breast development did not occur or was delayed more than pubic hair, but the delay in both secondary sexual characteristics was more marked than the delay in skeletal maturation (see also 5). At age 12, the average normal girl has moderate breast development (54), but at bone age 12 only $5.4 \%$ of our patients had moderate breast development and only $10.8 \%$ had moderate pubic hair.

As expected, a significantly larger $\%$ of non-XO patients underwent spontaneous menarche. Even non-XO patients who require estrogen treatment appear to have a more normal level of endocrine function than do XO patients, because they have significantly 
more pretreatment breast development and epiphyseal fusion. This is probably a reflection of their greater amount of functional gonadal tissue. The spectrum of gonadal development in Turner's syndrome varies all the way from apparently normal development, with menarche and pregnancy, to apparently no functional gonadal tissue. Non-XO's tend to be at the former end of the scale and XOs at the latter end. Weiss (61) observed histologically normal gonads in XO fetuses up to 3 months old, a higher incidence of $\mathrm{XO}$ infants with germ cells and primordial follicles, and a much lower incidence of these findings in older XOs, and suggested that germ cells are gradually lost at a rate that varies from patient to patient. This process appears to occur faster and be more extreme in XO than in non-XO patients. Further evidence of a gradual decline in gonadal function is that two of our patients with spontaneous menarche had very irregular periods, eventually requiring treatment, and that a third had secondary amenorrhoea at age 25 (Table 3). It is not possible to draw conclusions about the importance of specific segments of the $X$ chromosome for gonadal function, but in general it seems that the more $\mathrm{X}$ material present, the greater the chance of more normal gonadal function.

\section{REFERENCES AND NOTES}

1. Acheson, R. M. and Zampa, G. A.: Skeletal maturation in ovarian dysgenesis and Turner's syndrome. Lancet, $1: 917$ (1961).

2. Barlow, P.: The influence of inactive chromosomes on human development. Anomalous sex chromosome complements and the phenotype. Humangenetik, 17: 106 (1973).

3. Barr, M. L., Sergovitch, F. R., Carr, D. H., and Shaver, E. L.: The triple-X female: an appraisal based on a study of 12 cases and a review of the literature. Can. Med. Assoc. J., 10I: 247 (1969).

4. Bocain, M., Krmpotic, E., Szego, L., and Rosenthal, I. M.: Somatic stigmata of Turner's syndrome in a patient with 46 XXq-. J. Med. Genet., 8: 358 (1971).

5. Brook, C. G. D., Mürset, G., Zachman, M., and Prader, A.: Growth in children with 45 XO Turner's syndrome. Arch. Dis. Child., 49: 789 (1974).

6. del Castillo, E. B., de la Balze, F. A., and Argonz, J.: Syndrome of rudimentary ovaries with estrogenic insufficiency and increase in gonadotropins. J. Clin. Endocrinol., 7: 385 (1947).

7. de la Chapelle, A.: Cytogenetical and clinical observations in female gonadal dysgenesis. Acta Endocrinol., 40 (Suppl. 65): 1, (1962).

8. de la Chapelle, A., Schroder, J., and Pernu, M.: Isochromosome for the short arm of X, a human 46 XXpi syndrome. Ann. Hum. Genet., 36: 79 (1972)

9. Chen, A. T., Chan, Y. K., and Falek, A.: The effects of chromosome abnormalities on birth weight in man. I. Sex chromosome disorders. Hum. Hered., 21: 543 (1971)

10. Conen, P. E.: Chromosomal studies in endocrinology. In: Systematic Endocrinology. Ezrin, C. E., Godden, J. O., Volpe, T., and Wilson, R., (Eds.) pp. 259-310 (New York, Harper and Row, 1973).

11. Dalla Palma, L., Cavina, C., Guisti, G., and Borghi, A.: Skeletal development in gonadal dysgenesis, female in phenotype. Am. J. Roentgenol., 101: 876 (1967).

12. Engel, E. and Forbes, A. P.: Cytogenetic and clinical findings in 48 patients with congenitally defective or absent ovaries. Medicine, 44: 135 (1965).

13. Ferguson-Smith, M. A.: Karyotype-phenotype correlations in gonadal dysgenesis and their bearing on the pathogenesis of malformations. J. Med. Genet., 2: 142 (1965).

14. Ferguson-Smith, M. A., Alexander, D. S., Bowen, P., Goodman, R. M., Kaufman, B. N., Jones, H. W., Jr., and Heller, R. H.: Clinical and cytogenetical studies in female gonadal dysgenesis and their bearing on the cause of Turner's syndrome. Cytogenetics (Basel), 3: 355 (1964).

15. Finby, N. and Archibald, R. M.: Skeletal abnormalities associated with gonadal dysgenesis. Am. J. Roentgenol., 89: 1222 (1963).

16. Ford, C. E., Jones, K. W., Polani, P. E., de Almeida, J. C., and Briggs, J. H.: A sex-chromosome anomaly in a case of gonadal dysgenesis (Turner's syndrome). Lancet, 1: 711 (1959)

17. Gardner, L. 1.: Endocrine and Genetic Diseases of Childhood. p. 799 (Philadelphia Saunders, 1969).

18. Gartler, S. M. and Sparkes, R. S.: The Lyon-Beutler hypothesis and isochromosome X patients with the Turner syndrome. Lancet, 2: 411 (1963).

19. Greulich, W. W. and Pyle, S. I.: Radiographic Atlas of Skeletal Development of the Hand and Wrist. 2nd. ed. (Stanford University Press, Stanford, 1959).

20. Haddad, H. M., and Wilkins, L.: Congenital anomalies associated with gonadal aplasia. Review of 55 cases. Pediatrics, 23: 885 (1959).

21. Hauser, G. A.: Gonadal dysgenesis. In: Intersexuality, C. Overzier (Ed.) pp. 298-339 (Academic Press, New York, 1963).

22. Hecht, F., Jones, D. L., Delay, M., and Klevit, H.: Xq- Turner's syndrome: reconsideration of hypothesis that $\mathrm{Xp}$ - causes somatic features in Turner's syndrome. J. Med. Genet., 7: 1 (1970).

23. Hellinga, G.: Growth promoting treatment in small children; improvement of ultimate height with methyltestosterone. Acta Endocrinol., 18: 536 (1955)

24. Hook, E. B.: Behavioural implications of the human XYY genotype. Science 179: 139 (1973).

25. Hsu, L. Y. and Hirschhorn, K.: Genetic and clinical considerations of long arm deletion of the $X$ chromosome. Pediatrics, 45: 656 (1970).

26. Hsu, L. Y. and Hirschhorn, K.: Unusual Turner mosaicism (45,X-, 47 XXX $45, \mathrm{X}, \mathrm{X}-46, \mathrm{XXqi} ; 45, \mathrm{X}-46, \mathrm{XXr})$ : detection through deceleration from normal linear growth or secondary amenorrhea. J. Pediatr., 79: 276 (1971).

27. Jacobs, P. A.: Structural abnormalities of the sex chromosomes. Br. Med., Bull. 25: 94 (1969).

28. Johanson, A. J., Brazel, J. A., and Blizzard, R. M.: Growth in patients with gonadal dysgenesis receiving fluoxymesterone. J. Pediatr., 75: 1015 (1969).

29. Krogman, W.: Child Growth. p. 34 (Ann Arbor, Michigan, University of Michigan Press, 1972).

30. Leeming, B. W. A.: Endocrine control of skeletal development in man. Br. Med. J., 2: 358 (1962)

31. Lemli, L. and Smith, D. W.: The XO syndrome: a study of the differentiated phenotype in 25 patients. J. Pediatr., 63: 577 (1963).

32. Leszczynski, S. and Kosowicz, J.: Radiological changes in the skeletal system in Turner's syndrome: review of 102 cases. In: Progress in Radiology. Symposium of the 11 th International Congress of Radiology, Rome, 1965. pp. 510-517 (Amsterdam, Excerpta Medica Foundation, 1967).

33. Levin, B.: Gonadal dysgenesis, clinical and roentgenologic manifestations. Am. J. Roentgenol., 87: 1116 (1962)

34. Lindsten, J.: The nature and origin of $X$ chromosome aberrations in Turner's Syndrome; a cytologenetical and clinical study of 57 patients. p. 57, 142-143 (Stockholm, Almquist and Wiksells, 1963).

35. Lindsten, J., Filipsson, R., Hall, K., Leikrans, S., Gustavson, K. H., and Ryman, N.: Body height and dental development in patients with Turner's syndrome. Helv. Paediatr. Acta, (Suppl.) 34: 33 (1975)

36. Lippe, B. M. and Crandall, B. F.: Turner Syndrome with deletion of the $X$ chromosome long arm. Am. J. Dis. Child., 126: 222 (1973).

37. Lucky, A. W., Marynick, S. P., Rebar, R. W., Cutler, G. B., Glen, M., Johsonbaugh, R. E., and Loriaux, D. L.: Replacement oral ethinyloestradial therapy for gonadal dysgenesis; growth and adrenal androgen studies. Acta. Endocrinol., 91: 519 (1979).

38. Lyon, M. F.: Gene action in the X-chromosome of the mouse (Mus musculus L.). Nature, 190: 372 (1961).

39. Mattevi, M. S., Wolff, H., Salzano, F. M., and Mallmann, M. C.: Cytogenetic, clinical and genealogical analyses in a series of gonadal dysgenesis patients and their families. Humangenetik, 13: 126 (1971).

40. Migeon, B. R. and Kennedy, J. F.: Evidence for the inactivation of an X chromosome early in the development of the human female. Am. J. Hum. Genet., 27: 233 (1975).

41. Miller, O. J.: The sex chromosome anomalies. Am. J. Obs. Gynecol., 90: 1078 (1964).

42. Milne, J. S., Lauder, I. J., and Price, W. H.: Anthropometry in sex chromosome abnormality. Clin. Genet., 5: 96 (1974).

43. Mohandas, T., Shapiro, L. J., Sparkes, R. S., and Sparkes, M. C.: Regional assignment of the steroid sulphatase-X-linked ichthyosis locus: Implications for a noninactivated region on the short arm of human X chromosome. Proc. Natl. Acad. Sci. USA, 76: 5779 (1979).

44. Moore, D. C., Tattoni, D. S., Ruvalcaha, R. H. A., Leubeck, G. A., and Kelly, V. C.: Studies of anabolic steroids: J. Pediatr., 90: 462 (1973).

45. Park, M. E.: An Anthropometric and Radiographic Study of the Development of Individuals with Turner's Syndrome. Ph.D. Thesis. (Anthropology, University of Toronto, 1975).

46. Potasnick, A.: Gonadal dysgenesis: Report of a middle-aged patient with ununited epiphyses. S. Afr. Med. J., 45: 1364 (1971).

47. Preger, L., Steinbach, H. L., Moskowitz, P., Scully, A. L., and Goldberg, M. B.: Roentgenographic abnormalities in phenotype females with gonadal dysgenesis. Am. J. Roentgenol., 104: 899 (1968).

48. Root, A. W.: Endocrinology of puberty. I. Normal sexual maturation. J. Pediatr., 83: 1 (1973).

49. Rosenbloom, R. and Frias, J. L.: Oxandrolone for growth promotion in Turner's syndrome. Amer. J. Dis. Child., 125: 385 (1973).

50. Schibler, D., Brook, C. G. D., Kind, H. P., Zachmann, M., and Prader, A.: Growth and body proportions in 54 boys and men with Klinefelter's syndrome. Helv. Paedtr. Acta., 29: 325 (1974).

51. Simmons, K.: The Brush Foundation Study of Child Growth and Development II: Physical Growth and Development. Monograph of the Society for Research in Child Development, Ser. 37, No. 1. (Washington, D.C., Society for Research in Child Development, National Research Council, 1944).

52. Smith, D. W.: Recognizable Patterns of Human Malformation. Genetic Embryologic and Clinical Aspects. 2nd. Ed. p. 6-54 (Philadelphia, Saunders Co. 1976)

53. Snider, M. E. and Solomon, I. L.: Ultimate height in chromosomal gonadal dysgenesis without androgen therapy. Am. J. Dis. Child., 127: 673 (1974).

54. Tanner, J. M.: Growth at Adolescence. Ed. 2. Oxford, Blackwell, 1962.

55. Tanner, J. M., Prader, A., Habich, H., and Ferguson-Smith, M. A.: Genes on the $\mathrm{Y}$ chromosome influencing rate of maturation in man. Skeletal age studies in children with Klinefelter's (XXY) and Turner's (XO) syndromes. Lancet, 2: 141 (1959).

56. Turner, H. H.: Syndrome of infantilism, congenital webbed neck, and cubitus valgus. Endocrinology, 23: 566 (1938).

57. Turner, J. H., Charles, D., and Rankin, J. S.: Karyotypic aberrations in chromatin positive individuals with primary ovarian failure. J. Obs. Gynaecol. Brit Comm., 77: 536 (1970).

58. Urban, M. D., Lee, P. A., Dorst, J. P., Plotnick, L. P., and Migeon, C. J.: Oxandrolone therapy in patients with Turner's syndrome. J. Pediatr., 94: 823 (1979).

59. Usher, R., and McLean, $F .:$ Intrauterine growth of live-born Caucasian infants at sea level: standards obtained from measurements in 7 dimensions of infants 
born between 25 and 44 weeks of gestation. J. Pediatr., 74: 901 (1969).

60. Varney, R. F., Kenyon, A. T., and Koch, F. C.: Association of short stature, retarded sexual development and high urinary gonadotropin titers in women: ovarian dwarfism. J. Clin. Endocrinol., 2: 137 (1942).

61. Weiss, L.: Additional evidence of gradual loss of germ cells in the pathogenesis of streak ovaries in Turner's syndrome. J. Med. Genet., 8: 540 (1971).

62. Werff ten Bosch, J. J. van der: Factors that control or influence skeletal maturation. In: Somatic Growth of the Child, Eds. J. J. van der Werff ten Bosch and A. Haak, p. 38. (Leiden, Stenfert Kroese, 1966).

63. Wilkins, L. and Fleischmann, W.: Ovarian agenesis; pathology, associated clinical symptoms and bearing on theories of sex differentiation. J. Clin. Endocrinol., 4: 357 (1944).

64. Williams, E. C., Engel, E., and Forbes, A. P.: Thyroiditis and gonadal dysgenesis. N. Engl. J. Med., 270: 805 (1964).

65. Wright, E. V. and Scanlon, M. F.: X long-arm deletion with features of Turner's syndrome. Lancet, 1: 933 (1974).
66. Zacharias, J., Wurtman, R. J., and Schatzoff, M.: Sexual maturation in contemporary American girls. Am. J. Obstet. Gynecol., 108: 833 (1970).

67. The authors thank the subjects of the study and Dr. K. O. McCuaig (University of Toronto).

68. Requests for reprints should be addressed to: Dr. Elizabeth Park, Physical Growth and Development Clinic, The Hospital for Sick Children, Toronto, Ontario, Canada.

69. Elizabeth Park received financial support from the Medical Research Council of Canada during this project.

70. In all $t$ tests, appropriate corrections were made for small sample size and heterogeneity of variance. The 0.05 level of significance was used.

71. This rather loose system, rather than the more precise one devised by Tanner (54) was used to incorporate ratings made not using Tanner's system. Ratings and equivalent Tanner stages are 0 (I), 1 (II), 2 (III) 3 (IV,V).

72. Received for publication April 13, 1981

73. Accepted for publication March 2, 1982

Copyright (C) 1983 International Pediatric Research Foundation, Inc $0031-3998 / 83 / 1701-0001 \$ 0.200 / 0$ 